\title{
Comércio, política e ciência nas exposições internacionais \\ O Brasil em Turim, 1911. Parte 1
}

\section{Trade, Politics and Science in World's Fairs}

Brazil in Turin, 1911. Part 1

\section{Nelson SANJAD}

Programa de Pós-Graduação em História/Universidade Federal do Pará Museu Paraense Emílio Goeldi/MCTI

Av. Perimetral, 1901, Terra Firme, Belém, PA, 66.077-530, Brasil nsanjad@museu-goeldi.br

\section{Anna Raquel de Matos Castro \\ Programa de Pós-Graduação em História/Universidade Federal do Pará Travessa Quatorze de Abril, 1057, São Brás, Belém, PA, 66.060-460, Brasil annaraquelcastro@yahoo.com.br}

Resumo O artigo analisa a participação do Pará na Exposição Internacional da Indústria e do Trabalho em Turim, realizada em 1911. A mostra paraense reuniu, sobretudo, produtos oriundos do extrativismo e pode ser caracterizada pelo discurso científico, materializado, principalmente, pela presença de um renomado cientista na comissão organizadora, o botânico suíço Jacques Huber (1867-1914), à época diretor do Museu Goeldi, em Belém. As razões do destaque dado à ciência na exposição paraense de Turim e do envolvimento de um cientista em um certame comercial são estudadas a partir de três questões: as estratégias diplomáticas em jogo; o papel atribuído à ciência na organização da mostra; e as forças dissonantes na representação do país, perceptíveis na

\footnotetext{
Recebido: 04 de agosto de 2015 | Aprovado: 24 de agosto de 2015 http://dx.doi.org/10.1590/0104-87752015000300007 Varia Historia, Belo Horizonte, vol. 31, n. 57, p. 819-861, set/dez 2015
} 
dificuldade de elaborar um discurso nacional e na distância entre uma sociedade profundamente desigual e a imagem que se construiu dessa mesma sociedade. (A parte 2 deste artigo será publicada na próxima Varia Historia, vol. 32, n. 58, janeiro-abril 2016)

Palavras-Chave exposição, borracha, representação

Abstract The article analyses the participation of the Brazilian State of Pará at the International Exposition of Industry and Work in Turin, 1911. The Pará exhibition brought together especially products from the extractivism and may be characterized by its scientific discourse, materialized mainly by the presence of a renowned scientist in the organizing committee, the Swiss botanist Jacques Huber (1867-1914), then Director of the Goeldi Museum in Belém. The reasons to highlight science in the Pará exhibition and for the involvement of a scientist in a commercial event are studied through the following questions: the diplomatic strategies that took place in Turin; the role given to science in the organization of this world's fair; and the dissonant forces in the representation of Brazil, noticeable on the difficulty of drawing up a national discourse and on the distance between a deeply unequal society and the image that was built of this same society. (The second part of this article will be published in next Varia Historia, vol. 32, n. 58, january-april 2016)

KEYWORDS exposition, rubber, representation

\section{INTRODUÇÃO}

A segunda metade do século XIX e as primeiras décadas do XX foram marcadas pela frequência de realização de exposições internacionais, sobretudo na Europa e nos Estados Unidos, como momentos de mobilização e celebração da indústria, do comércio, do desenvolvimento científico e tecnológico e da instrução pública. Nesse período, o mundo experimentou rápidas transformações no âmbito econômico, político e social. Consolidou-se o sistema de fábricas, o capitalismo e o 
colonialismo expandiram-se e uma nova classe ascendeu, a burguesia. Ideais de 'modernidade' e 'civilização', ainda que difusos, pautaram o debate público enquanto partes constituintes do imaginário burguês eurocêntrico e justificaram intervenções econômico-sociais, político -ideológicas e militares nos quatro cantos do mundo. As exposições internacionais foram, a um só tempo, espelho e motor desse processo (Harvey, 1996).

Este artigo ocupa-se de um desses eventos, realizado de 29 de abril a 19 de novembro de 1911 na cidade de Turim. Trata-se da Exposição Internacional da Indústria e do Trabalho, a última grande mostra realizada antes da Primeira Guerra Mundial e a única montada na Itália até então. Esses são motivos suficientes para que a exposição de Turim receba atenção especial. A importância política da mostra justifica-se não somente porque celebrou o cinquentenário da unificação da Itália, a rápida industrialização do norte do país e o poderio econômico da Casa de Saboia, como também porque prenunciou um iminente conflito europeu: pela primeira vez na história das exposições internacionais, um país participante - Alemanha - fez clara afronta aos demais ao exibir grande quantidade de armas sob uma cúpula de 42 metros de altura encimada com a coroa imperial. Outro fato demonstrou que algo não ia bem naquela 'arena pacífica': o Pavilhão da Turquia foi fechado em setembro de 1911, quando a Itália declarou guerra ao país em razão da disputa pela Cirenaica e Tripolitânia (atual Líbia). Contudo, se a mostra turinesa pode ser estudada em função das transformações políticas e econômicas da Itália e dos conflitos da Europa pré-guerra, ela também o pode pelo desenvolvimento tecnológico e pelos modismos que anunciou. Esta foi a primeira grande feira de aviação e automobilismo, apresentou a Estrada de Ferro Elétrica e inovou com a intensa programação esportiva, com o Pavilhão da Cidade Moderna - no qual foram sistematizados a infraestrutura e os serviços que toda cidade 'civilizada' deveria ter - e com o Palácio da Moda, que promovia a aliança entre arte, indústria têxtil e comércio. ${ }^{1}$

1 MORIONDO, 1981; LEVRA; ROCCIA 2003; BASSIGNANA, 2006; COLETTA, 2006; 
O Brasil se fez representar com destaque nessa exposição e competiu acirradamente com a Argentina, cujo pavilhão monumental recebeu especial atenção da comissão organizadora em razão dos laços comerciais e culturais com a Itália, sendo o primeiro do roteiro de pavilhões nacionais posicionados às margens do rio Pó. O pavilhão brasileiro era bem menos imponente, mas significativo em termos espaciais -8.000 metros quadrados de área, divididos em três prédios com extensão total de 150 metros - e bem localizado, na sequência do Pavilhão da América Latina e anterior aos pavilhões belga, francês e alemão (Figura 1). A geopolítica da exposição era clara: no começo do século XX, a Itália despontava como um dos grandes parceiros comerciais da Argentina e do Brasil. Ambos os países vinham recebendo levas de imigrantes italianos e haviam ingressado na rota das empresas italianas de navegação transoceânica. Capitais provenientes da Itália afluíam nesses países e eram destinados ao crédito, à lavoura e à indústria, ou seja, a exposição turinesa surgiu como boa oportunidade para divulgar mercados em expansão e estabelecidos sobre sólidas relações culturais.

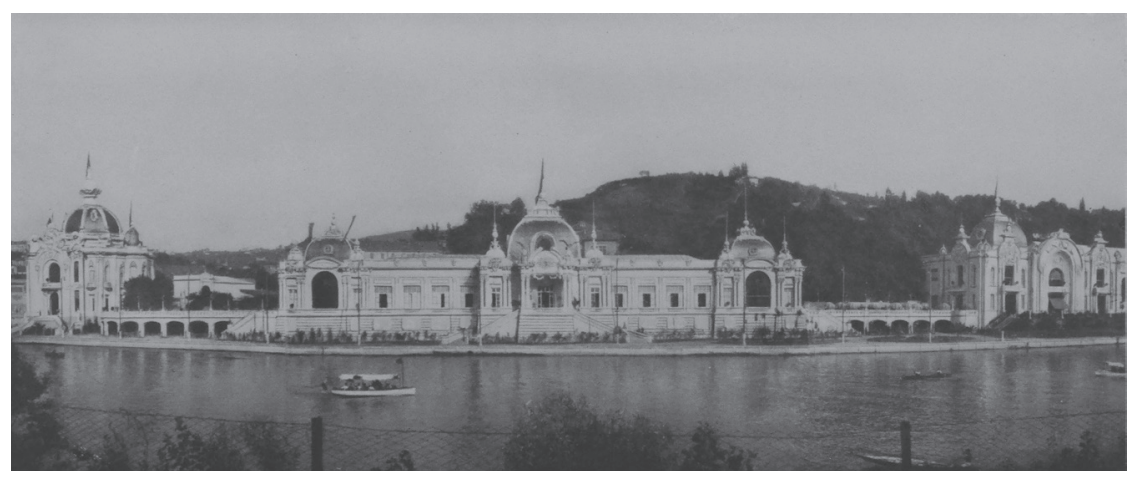

Figura 1. Os três prédios do pavilhão brasileiro na Exposição Internacional da Indústria e do Trabalho em Turim, 1911. Fotografia publicada em Martins et al. (1911, p.7).

BALOCCO, 2011; MASSARI, 2012. 
Entre os estados brasileiros, São Paulo e Pará foram os que mais investiram na mostra. Não por coincidência, suas respectivas exposições exibiam, entre outros, os produtos que lideravam as exportações nacionais, o café e a borracha. Havia algo, contudo, que distinguia a mostra paraense: o discurso científico, materializado pela exibição de amostras botânicas, fotografias, instrumentos para 'sangrar' seringueiras, máquinas para processar o látex e, principalmente, pela presença de um renomado cientista na comissão organizadora da mostra, o botânico suíço Jacques Huber (1867-1914), à época diretor do Museu Goeldi, em Belém, e ativo delegado paraense em eventos internacionais. A mostra turinesa foi a que mais exigiu dedicação e empenho de Huber, não apenas nas atividades de organização e supervisão, como também na representação diplomática do estado do Pará (Sanjad, 2003; Cunha, 2009; Castro, 2013).

As razões do destaque dado à ciência na exposição paraense de Turim e do envolvimento de um cientista em questões de ordem política, em um contexto de tensões internacionais e acirrada competição comercial, serão analisadas neste artigo. Pretendemos levantar três questões, imbricadas umas nas outras. Em primeiro lugar, a dimensão política do evento, uma vez que a participação de um país em exposições internacionais tinha propósitos claros, isto é, a forma como cada país era representado obedecia a estratégias diplomáticas e comerciais previamente estabelecidas. Isto implica considerar que o discurso adotado em cada pavilhão nacional - da arquitetura do edifício a cada um dos objetos exibidos - tinha coerência e uma intenção. A segunda questão é a dimensão científica do evento, aqui entendida não apenas em razão dos conteúdos de cariz científico e tecnológico presentes nas exposições ou dos congressos que ocorriam em paralelo, mas também da racionalidade intrínseca às exposições internacionais, que permitia, em um conjunto de cenas fragmentadas, a classificação de saberes e objetos, a comparação de imagens, o contraste entre diferentes nações, a medição da distância entre o 'desenvolvido' e o 'atrasado'. Nesse sentido, a ciência surge não apenas como produto a ser exposto e consumido, mas também como visão de mundo que ordenava a própria percepção das 
coisas. A última questão remete à construção do nacionalismo e seu tema correlato, a folclorização, a estereotipagem e/ou o apagamento da alteridade, incluindo o regional. Na historiografia, essa questão tem sido muito mais abordada em razão das diferenças nacionais dentro da Europa, sobretudo entre França e Alemanha, ou a partir do esforço feito por distintos governos para criar um consenso em torno da unidade nacional, geralmente baseado em atributos econômicos e culturais, como são os casos dos Estados Unidos, do México, da Espanha, Itália e Suíça. ${ }^{2}$ Menos frequentes são os estudos sobre a representação da diversidade social, cultural e étnica de um mesmo país, isto é, como essa diversidade é interpretada ou mesmo apagada (Peer, 1998). Essa segunda perspectiva é particularmente interessante para o caso do Brasil, pois permite identificar forças políticas dissonantes na construção de um discurso nacionalista e também o viés histórico-racial utilizado sempre que o 'índio', o 'nativo', o 'selvagem', o 'negro' ou o 'mestiço' era inserido nas mostras nacionais e internacionais. ${ }^{3}$

Essas três questões alinham-se aos objetivos deste artigo, a saber, analisar a participação do estado do Pará na Exposição Internacional da Indústria e do Trabalho, em Turim, tendo em vista o contexto em que foi organizada e o envolvimento de um cientista na organização da mostra. Adotamos uma perspectiva historiográfica denominada "escola da hegemonia cultural", caracterizada pelo pressuposto de que as exposições internacionais seriam parte das agendas nacionais e/ou imperiais dos países que sediavam os eventos (Rydell; Findling; Pelle, 2000, p.19-20). Enquanto "universos simbólicos", agiam por meio da ideologia para conquistar os corações e as mentes das massas que acorriam aos milhões para usufruir de um espaço considerado próximo ao maravilhoso. Os conceitos de representação, imagem e discurso são, portanto, intrínsecos a essa perspectiva, no sentido de que permitem acessar narrativas

2 PESSOLANO; BIANCO, 1988; TENORIO-TRILLO, 1996; FISCHER, 1999; COLETTA, 2006; STORM, 2010; RUEDIN, 2010; FISS, 2010.

3 TENORIO-TRILLO, 1994; ANDERMANN, 2004; ANDERMANN, 2007; SANCHEZ ARTEAGA; NINO EL-HANI, 2010; REZENDE, 2010; SCHUSTER, 2014. 
político-ideológicas perceptíveis na organização do espaço, na cultura material e visual ali articulada para celebrar a grandeza dos EstadosNação e a hegemonia cultural de matriz europeia e burguesa.

O trabalho está dividido em duas partes: na primeira, aqui publicada, apresentaremos, em linhas gerais, a exposição de Turim e a representação brasileira na mostra. Esse passo é fundamental porque, mesmo em nível internacional, essa exposição não foi suficientemente estudada, se comparada com as realizadas na França, na Inglaterra e nos Estados Unidos. No Brasil, pouquíssimos autores ocuparam-se da mostra, e apenas de maneira superficial. ${ }^{4}$ Cabe, portanto, identificar seu potencial para futuras investigações e destacar sua importância política e cultural. Em seguida, analisa-se o desempenho da seção brasileira na mostra turinesa, com destaque para a indústria paraense. Procura-se caracterizar a mostra organizada pelo estado do Pará com base nos expositores que dela participaram, bem como as razões que presidiram a organização da mostra e os critérios utilizados para a seleção dos produtos e para a elaboração do material propagandístico impresso e audiovisual. $\mathrm{Na}$ segunda parte, a ser publicada no próximo número desta revista, demonstra-se, por meio da correspondência dos delegados paraenses, os percalços da montagem dos pavilhões brasileiros, as difíceis condições de trabalho, as diferenças entre o planejado e o realizado, as disputas por espaço entre os delegados estaduais. Também se descreve em detalhe o stand da borracha, tendo em vista os propósitos do governo e dos delegados paraenses. Por fim, aborda-se a atuação diplomática dos delegados brasileiros, seja por meio da participação no júri internacional, seja na representação de interesses governamentais e comerciais. Mais uma vez, são analisados os delegados paraenses, o que lhes foi exigido e como se articularam para desempenhar suas funções. Ao longo de todo o artigo, a atuação de Jacques Huber é enfatizada com a finalidade de demonstrar seu papel na comissão organizadora do estado do Pará e como a ciência, por meio de um representante bem conhecido, foi acionada

4 SANTOS; COSTA, 2005; SANTOS; COSTA, 2006; SANTOS; COSTA, 2012; SANTOS, 2009; SÃO PAULO, 2014. 
para afiançar não apenas a qualidade da borracha amazônica, em competição com a do Oriente, como também para garantir aos importadores que a produção amazônica de látex estava sendo aperfeiçoada.

Nosso estudo baseou-se em fontes impressas, como relatórios, jornais e fotografias, e em manuscritos preservados no Museu Paraense Emílio Goeldi (Belém, Pará), instituição que conserva registros da participação paraense nas exposições nacionais e internacionais realizadas durante a Primeira República, no Staatsarchiv des Kantons Basel-Stadt (Basileia, Suíça), onde está depositada parte do arquivo pessoal de Jacques Huber, e na Biblioteca Pública Arthur Vianna (Belém, Pará). Também foram consultados documentos pertencentes ao Archivio Storico della Città di Torino (Turim, Itália), onde existe um enorme fundo documental sobre as exposições realizadas nesta cidade desde o início do século XIX. Três bibliografias disponíveis na internet e um website foram importantes para este trabalho. ${ }^{5}$

\section{A PRIMEIRA EXPOSIÇÃO INTERNACIONAL REALIZADA NA ITÁlia: TURIM, 1911}

A Itália ingressou no século XX tentando superar as dificuldades econômicas e os conflitos políticos que marcaram a década de 1890 , sobretudo a falta de consenso entre a classe dirigente liberal e o avanço do Partido Socialista. Naquela década, o país experimentou grave desemprego e muitas agitações políticas, seguidas de violenta repressão por parte do governo, que não apenas fragilizavam o liberalismo como também a própria monarquia constitucional sob a égide da Casa de Saboia, implantada em 1861, ano da unificação política. A ascensão de Vittorio Emanuele III, em 1900, após um anarquista assassinar seu pai, Umberto I, evidenciou a necessidade de um consenso político no país e provocou uma rearticulação de forças. Em 1905, o governo já divisava o 'ano fatal' de 1911 como marco estratégico da política interna e

5 BURKE; SERAFICA; HIGGINS, 2005; GEPPERT; COFFEY; LAU, 2006; BIBLIOTECHE CIVICHE TORINESE, 2006; COLETTA, 2009. 
externa, capaz de organizar as energias políticas locais em prol da união nacional. As comemorações do jubileu do Reino da Itália foram, nesse sentido, planejadas para valorizar o governo unitário e as consequências econômicas, sociais e culturais advindas da integração, e também para lançar o país no cenário global como potência industrial e militar. Um conjunto de exposições e eventos - artísticos, comerciais, industriais, científicos e desportivos - foi organizado, envolvendo muitos segmentos da sociedade italiana em torno de um discurso nacionalista voltado para o consumo interno e da construção da imagem de uma Itália unida e forte, projetada internacionalmente. Os principais acontecimentos tiveram lugar em Turim, Florença e Roma, as três capitais do novo reino. Em vez de organizar uma exposição universal concentrada em uma única cidade, como vinha acontecendo em outros países, a estratégia do governo italiano foi descentralizar os eventos e realizar mostras internacionais separadas, multipolares, evitando disputas internas e capitalizando os ganhos políticos advindos de uma iniciativa que deveria ter, como fim último, a união nacional (Levra; Roccia, 2003; Coletta, 2006).

As comemorações em Florença foram abertas em março de 1911, com duas mostras: "Mostra do Retrato Italiano do final do século XVI a 1861" e "Exposição Internacional de Floricultura". Alguns autores consideram ambos os eventos como simbólicos, mas o fato é que Florença já era um dos principais destinos turísticos da Europa e os eventos ali realizados contribuíram para confirmar uma vocação turística baseada no consumo da arte e da paisagem toscana. Roma, por sua vez, sediou várias exposições, sendo as principais: "Topografia Romana”; "Retrospectiva sobre Roma Medieval e Moderna"; "Mostra do Ressurgimento [Risorgimento]"; "Revisão [Rassegna] Internacional de Arte Contemporânea"; e "Exposição Etnográfica das Regiões", abertas entre março e junho de 1911. As mostras tinham como objetivo apresentar a história milenar da Cidade Eterna, centro irradiador de arte e cultura para a civilização ocidental, e também elaborar uma narrativa histórica da nação italiana, cujo ponto de inflexão teria sido o período compreendido entre 1815 e 1870, o Risorgimento, marcado por movimentos revolucionários, guerras e lutas da unificação, lideradas pelo então rei 
de Piemonte-Sardenha, Vittorio Emanuele II. A "Exposição Etnográfica” é considerada a maior das mostras romanas, uma viagem pelo Reino da Itália através de 14 pavilhões regionais, que apresentavam produtos, monumentos e paisagens típicos de cada território, além de quarenta grupos etnográficos formadores da jovem nação. Esta complexa narrativa expográfica, com implicações históricas, antropológicas, geográficas e políticas, foi montada em vários pontos da cidade, que passou por uma grande reforma urbana, incluindo o restauro e a renovação de construções da Antiguidade (Palombi, 2009; Massari, 2012).

A despeito da importância de Roma, antiga capital dos Estados Pontifícios, os últimos a serem anexados ao Reino, em 1870, a mais importante exposição do jubileu italiano foi montada em Turim, capital do Piemonte e sede da Casa de Saboia. A cidade foi considerada 'berço' da nação por causa da liderança de Vittorio Emanuele II e seu ministro Camillo Benso, o Conde de Cavour, no duro processo de unificação. Em 1911, a cidade contava 450 mil habitantes e já possuía um parque industrial significativo, sendo conhecida como a Manchester da Itália. Esse processo de modernização teve início ainda na década de 1860, quando a cidade perdera a função de capital do reino e, consequentemente, viu sua população diminuir, postos de trabalho e instituições públicas fecharem e a economia entrar em uma fase de depressão geral. O governo local estabeleceu, então, uma estratégia de recuperação baseada em incentivos fiscais para indústrias e em obras de infraestrutura, sobretudo nos sistemas de comunicação, transporte e aproveitamento energético. A pesquisa tecnológica foi largamente incentivada, principalmente na área de engenharia. Por exemplo, em 1888, foi inventado em Turim, por Galileu Ferraris, o alternador elétrico, que permitiu o desenvolvimento do circuito polifásico, do transformador e, consequentemente, da geração de hidroeletricidade e a eletrificação de longa distância. Pesquisas nas áreas de eletricidade, combustão e mecânica também possibilitaram o aperfeiçoamento do motor e a implantação, na cidade, de um polo de produção de automóveis, a Fabbrica Italiana Automobili Torino (FIAT), inaugurada em 1899 por Giovanni Agnelli (Moriondo, 1981; Balocco, 2011). 
Nesse sentido, o contraste estabelecido entre Roma e Turim era simbólico: enquanto a capital espiritual e intelectual exibia o glorioso passado nacional, a capital da produção e do progresso mostrava um país aberto para o futuro. De acordo com os autores que analisaram o conjunto de exposições italianas abertas em 1911, a distinção entre Roma e Turim revelava uma dicotomia entre cultura humanística e economia, característica do liberalismo burguês, além de uma frágil identidade cultural, social e econômica. Essa distinção também ajuda a entender as contradições da celebração turinesa, que exaltava a democracia industrial ao mesmo tempo em que omitia os problemas sociais decorrentes da industrialização europeia e anunciava os projetos expansionistas e coloniais da Itália. Em uma perspectiva comparada, pode-se pensar a mostra turinesa como a celebração de uma metrópole de industrialização tardia e que reclamava um lugar especial nas narrativas nacionais, tal como ocorreu com a Chicago da Exposição Columbiana de $1893 .{ }^{6}$

A Exposição Internacional da Indústria e do Trabalho foi construída no parque do Castelo Valentino, às margens do rio Pó. O local era palco e cenário das mostras turinesas desde 1829, quando teve início uma série de exposições da indústria e das belas artes do Piemonte, promovida pela Câmara da Agricultura e do Comércio e seguindo uma tradição iniciada na França napoleônica. Na década de 1850, o Castelo foi inteiramente restaurado e remodelado para abrigar grandes exposições, inauguradas em 1858 com a Sexta Exposição Nacional de Produtos da Indústria, já sob influência das mostras de Londres (1851) e Paris (1855). A Exposição Geral Italiana em Turim, promovida pela Sociedade Promotora da Indústria Nacional em 1884, foi outro importante marco, pois ressaltou as transformações econômicas, políticas e sociais da Itália unificada e a passagem de Turim de capital política para capital industrial. Em 1898, o Real Valentino abrigou uma das mais importantes mostras realizadas na Itália, a Exposição Geral e de Arte Sacra, que celebrava os 50 anos do Estatuto Albertino, Constituição adotada no reino sardo-piemontês.

6 PICONE PETRUSA; PESSOLANO; BIANCO, 1988; LEVRA; ROCCIA, 2003; PALOMBI, 2009; GURSEL, 2010. 
A dupla mostra, sem precedentes na história italiana, foi interpretada como marco da aliança entre liberais e católicos, além de ter sido usada para desviar a atenção dos conflitos populares decorrentes do desemprego e da carestia, e da forte repressão do governo monárquico. ${ }^{7}$

No início do século XX, o Castelo Valentino, com seu parque contíguo, já se configurava como lugar de memória para a nação italiana, não apenas por ter abrigado importantes exposições nacionais do Risorgimento e do novo Reino, mas também por ser a sede da Régia Escola de Aplicação para Engenheiros, criada em 1859 e transformada em Régio Politécnico após a fusão com o Museu Industrial, em 1906. O edifício, por si próprio, evocava o desenvolvimento tecnológico e industrial de Turim, celebrava a memória de várias gerações de engenheiros e empreendedores locais e foi considerado como vitrine para a primeira exposição internacional da Itália.

A favolosa esposizione, como ficou conhecida, estendia-se por 1.200 mil metros quadrados, dos quais 350 mil eram edificados. Seu tema central era o desenvolvimento econômico, cuja base era entendida como sendo a indústria de transformação e o trabalho. Deveriam estar representados, portanto, todos os ramos industriais conhecidos no início do século XX, além de serem caracterizadas as principais profissões por meio de seus instrumentos e atividades. O 'trabalho' aparecia, nesse sentido, de maneira a dignificar o trabalhador enquanto principal elemento da produção - sem nenhum destaque às contradições e assimetrias que perpassam o sistema capitalista, objetos das críticas e razão da militância dos movimentos socialistas e anarquistas daquela época. O fio condutor da mostra tinha início nos recursos naturais, isto é, nos produtos minerais, vegetais e animais, assim como nos fenômenos físicos que a natureza oferece ao gênio humano, com suas respectivas utilidades e aplicações sociais; prosseguia com os processos de transformação desses recursos, desde os mais simples até os mais sofisticados e complexos, postos em ação para que gerem o progresso e o bem estar da

7 PICONE PETRUSA; PESSOLANO; BIANCO, 1988; LEVRA; ROCCIA, 2003; COLETTA, 2006; BASSIGNANA, 2006. 
humanidade; apresentava a infraestrutura necessária para que os produtos manufaturados cheguem ao mercado e circulem pelo mundo; a legislação e o arcabouço jurídico que regulam as relações econômicas e a distribuição da riqueza; e as formas de garantir paz e segurança, de maneira que a produção e as relações econômicas sejam efetivadas e o desenvolvimento crie raiz no tecido social. Esse conjunto de temas, circular e tautológico, utópico, posto que livre de máculas e conflitos, formava uma narrativa-síntese do liberalismo econômico que imperou na chamada Belle Époque, um resumo da sociedade burguesa tal qual era concebida pelas elites governantes da Europa, como se desejassem perpetuar sua memória diante de um possível e dramático desfecho. Os principais prédios erguidos no parque Valentino atestam e representam a narrativa expográfica. ${ }^{8}$ Excetuando a Itália, 29 países se fizeram representar, mas nem todos com pavilhões próprios, além da Índia e das Colônias Francesas. Os maiores pavilhões nacionais eram os da Inglaterra, Alemanha, França, Bélgica, Argentina e Brasil (Moriondo, 1981; Coletta, 2006; Balocco, 2011).

O pavilhão brasileiro foi o primeiro a ser anunciado no Giornale Ufficiale Illustrato dell'Esposizione Internazionale delle Industrie e del Lavoro, em setembro de 1910. Segundo os redatores, o país havia decidido participar da exposição com uma "mostra verdadeiramente importante", a ser montada em três prédios ligados por uma "elegante galeria", defronte dos jardins da Villa Medici. O projeto arquitetônico, que celebrava o revival do barroco brasileiro, havia sido assinado por J. Moraes Rego, Jayme Figueira e Júlio Antônio de Lima, e os trabalhos de organização eram coordenados pessoalmente pelo ministro da Agricultura, Indústria e Comércio, Rodolfo de Miranda, considerado um "amigo dos

8 Foram eles: Palácio da Moda; Arte Aplicada à Indústria; Cidade Moderna; Caça, pesca e aquário; Correios, Telefone e Telégrafos; Eletricidade; Imprensa e Artes Gráficas; Galeria das Máquinas em Ação; Materiais Ferroviários; Viação, automóveis e aeronáutica; Agricultura e máquinas agrárias; Indústria extrativa e química; Defesa dos países; Indústria manufatureira; Indústria têxtil; Mineração e metalurgia; e Pavilhão do Festival, conectado com o Pavilhão da Música por ampla galeria contendo exposições sobre as "maravilhas da eletricidade" (incluindo $\mathrm{o}$ alternador de Ferraris, os usos do raio $\mathrm{X}$ e os fascinantes fornos elétricos) e ainda sobre o ensino profissional, instrumentos musicais, materiais cênicos e cinematográficos. 
italianos" por reconhecer-lhes a importância no "engrandecimento" de seu estado natal, São Paulo, "o mais evoluído do Brasil". Segundo o jornal, o ministro reconhecia que a "grande festa do trabalho oferece uma excelente ocasião para mostrar como os italianos trabalham no Brasil e quanto progresso se tem feito, nos últimos anos, neste vasto e rico país". 9 propaganda da imigração italiana iria, de fato, ser um argumento central para justificar os investimentos feitos pelo governo brasileiro, assim como o destaque dado ao Brasil - e aos dois outros países americanos que mais receberam imigrantes, Argentina e Estados Unidos - pelos organizadores da mostra. ${ }^{10}$ As informações então divulgadas, relatando histórias de famílias, as dificuldades encontradas pelos imigrantes, oportunidades de trabalho e exemplos de pessoas consideradas bem sucedidas, geraram várias notícias de jornal e panfletos. ${ }^{11}$

Os dois prédios laterais seriam destinados à "exposição geral dos produtos brasileiros" e o central "às festas, distribuição de café, chocolate, cacau, mate; exibição de fitas cinematográficas, projeções luminosas, panoramas, vistas etc.. ${ }^{12}$ Conforme as instruções aos expositores, publicadas pelo governo brasileiro, a representação do país em Turim fazia-se prioritária devido às "grandes relações comerciais e os interesses vários que vinculam o Brasil e a Itália". Recomendava-se "máximo empenho" nas seções de indústrias agrícolas, fabris e extrativas, com o fim de "demonstrar não só a pujança e fertilidade do solo brasileiro, como ainda, em muitos casos, a superioridade dos nossos produtos, e permitir favorável cotejo com os similares de outros países". ${ }^{13}$ Especial destaque

9 LA PARTECIPAZIONE DEL BRASILE. Giornale Ufficiale Illustrato dell'Esposizione Internazionale delle Industrie e del Lavoro (Turim), p.133, n. 9, 1910.

10 BRASIL. Exposição Internacional das Indústrias e do Trabalho. Turim-Roma, abril a outubro de 1911. Secção Brasileira. Rio de Janeiro: Officinas Graphicas do Jornal do Brasil, 1910; SÃO PAULO. Secretaria do Trabalho, Indústria e Comércio. Studio comparativo sullintercambio fra l'Italia, il Brasile e lo stato di S. Paolo. São Paulo: Dupart \& Comp., 1911.

11 SAINI, E. Dove vive un milione d'italiani: lo Stato di San Paolo nel Brasile. Milão: Fratelli Treves, 1911.

12 BRASIL. Exposição Internacional das Indústrias e do Trabalho.

13 BRASIL. Exposição Internacional das Indústrias e do Trabalho, p.2. 
deveria ser dado ao café, único produto brasileiro de exportação mencionado na "Exposição de Motivos" apresentada pelo ministro Rodolfo de Miranda ao presidente Nilo Peçanha. A participação brasileira na mostra turinesa era vista com grande otimismo, uma vez que poderia "contribuir para se resolver a crise do café, que abalou os fundamentos da fortuna pública e particular, e prevenir as [crises] que se possam dar com relação a outros produtos, por cujo desenvolvimento devemos propugnar facilitando a sua introdução nos mercados externos em concorrência com os similares de outras procedências". ${ }^{14}$

A comissão executiva brasileira era formada, além do ministro, por Antônio de Pádua Assis Rezende, Comissário Geral, substituído em julho de 1911 por Joaquim Cândido da Costa Sena, diretor da Escola de Minas de Ouro Preto; Mário Cardim, Secretário Geral; Francisco de Avellar Figueira de Mello, do Museu Comercial do Rio de Janeiro; vários comissários adidos e os delegados dos estados da Bahia, Minas Gerais, Pará, Pernambuco e São Paulo. A maior delegação era a do estado do Pará, com três representantes oficiais, João Antônio Rodrigues Martins, Cônsul Geral do Brasil na Itália e membro de tradicional família paraense, Jayme Pombo da Gama e Abreu, filho do Barão de Marajó, e Jacques Huber, diretor do Museu Goeldi (Figura 2). Por solicitação de Costa Sena, Abreu e Huber passaram a ser assistentes do Comissariado Geral a partir de agosto de 1911, formando o quarteto, juntamente com Figueira de Mello, que gerenciou, na prática, o espaço brasileiro na feira turinesa. A comissão executiva brasileira tinha como principais tarefas - além da construção do pavilhão, da montagem da exposição e da representação diplomática do país junto ao governo italiano - a articulação com os governos estaduais, municipais, associações comerciais, agrícolas e expositores privados, de maneira a obter os melhores e mais variados produtos da indústria nacional, e a organização de um "plano de propaganda prática do café" no exterior, incluindo providências para facilitar a compra, a venda e o transporte do produto para mercados europeus. ${ }^{15}$

14 BRASIL. Exposição Internacional das Indústrias e do Trabalho, p.4.

15 BRASIL. Exposição Internacional das Indústrias e do Trabalho. 


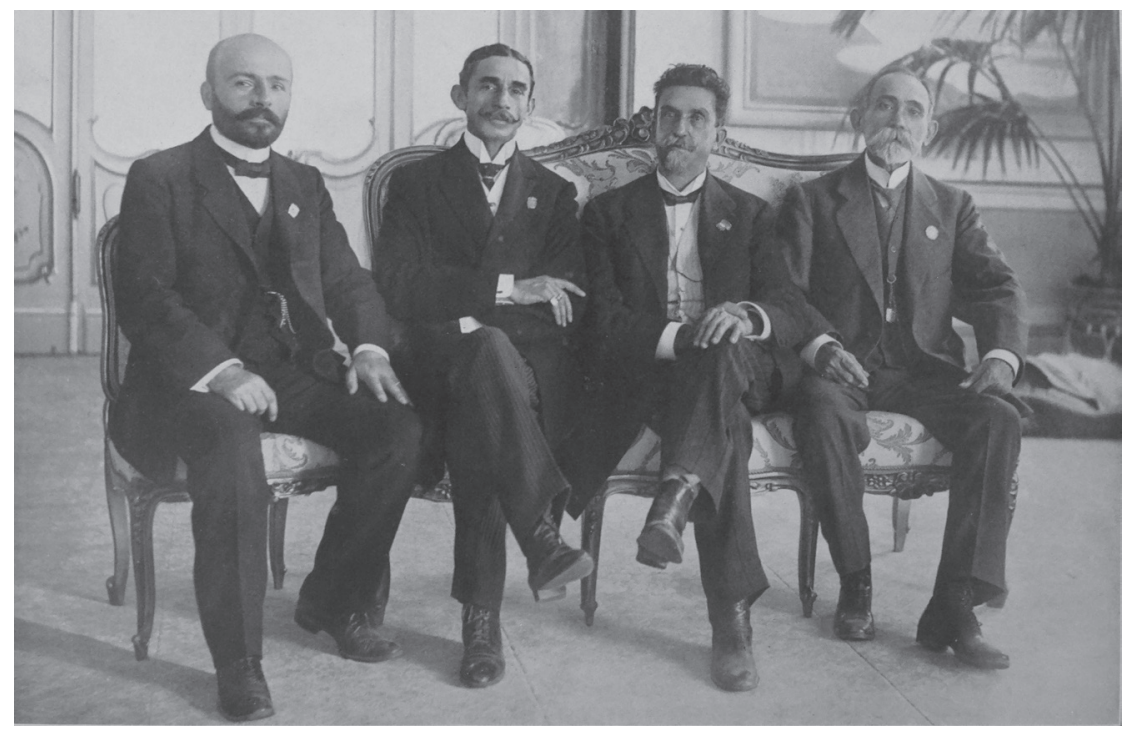

Figura 2. Fotografia publicada em Martins et al. (1911, p.109), com a seguinte legenda: "O Commissario Geral do Brazil e os membros da Delegação Paraense na Exposição Internacional de Turim em 1911. Dr. Jacques Huber. Jayme Gama e Abreu. Dr. J. C. Costa Sena. Comm dor João A. Rodrigues Martins, Pre ${ }^{\text {te." }}$

No primeiro relatório da comissão, datado de dezembro de 1910 e assinado por Rezende, é apresentado um minucioso estudo sobre o comércio do café brasileiro em nível mundial, com destaque para os problemas da produção agrícola e do processamento, os principais portos importadores da Europa e os mercados com potencial de expansão, como Áustria-Hungria, Itália e Rússia. Na segunda parte, são apresentadas as atividades de organização da exposição propriamente ditas, ficando claro que o fim último da participação brasileira era a "expansão econômica dos produtos nacionais e a reputação de nossos créditos de país civilizado". ${ }^{16}$ Após comparar a infraestrutura da Exposição Nacional

16 REZENDE, A. P. A. Relatorio sobre os trabalhos da Commissão do Brazil na Exposição TurimRoma de 1911 e Propaganda do Café no Extrangeiro apresentado ao Snr. Ministrado da Agricultura, Industria e Commercio pelo Commissario Geral Dr. Antonio de Padua Assis Rezende em 31 de dezembro de 1910. Turim: 1911, p.78. 
brasileira (1908), a de Bruxelas (1910) e a de Turim, chamando a atenção para a importância do local das mostras e criticando a falta de "uniformidade" dos expositores brasileiros e a inexistência, no país, de um serviço especializado, que planejasse com antecedência e concentrasse as atividades, Rezende apresenta a organização geral do evento turinês e sua proposta de representação "unificada" do Brasil, "dando-lhe fórmula sugestiva e convincente". ${ }^{17}$ Essa proposta tinha início na concepção dos edifícios, cujos projetos arquitetônicos tiveram de ser reformulados em razão das "irregularidades do terreno", não previstas pelos arquitetos e engenheiros brasileiros. Consequentemente, as obras tiveram início somente em setembro, com grande atraso. ${ }^{18}$

$\mathrm{Na}$ nova concepção unificada de Rezende, os estados não teriam seus respectivos stands. Todos os produtos seriam organizados conforme sua classificação, e não conforme a proveniência. Nesse sentido, o Pavilhão Central, antes concebido para festas, degustações, espetáculos e exibição de fitas cinematográficas, seria destinado à exposição de produtos e decorado com vitrais, pinturas alegóricas e "fotografias transparentes e coloridas". ${ }^{19}$ De acordo com a lógica de Rezende, seus 1.367 metros quadrados deveriam acolher, de um lado, a indústria extrativa (mineral, vegetal e animal), de outro, a agricultura e, no centro, com o devido destaque, o café. ${ }^{20} \mathrm{O}$ prédio da esquerda, com 817 metros quadrados,

17 REZENDE, A. P. A. Relatorio..., p.86.

18 REZENDE, A. P. A. Relatorio...

19 Os títulos eram sugestivos: "A colheita do café", "Pesca no Brasil", "O Brasil apresentando às diversas nações do Mundo os seus diferentes produtos", "Agricultura" e "Caravelas portuguesas singrando os mares a caminho da América”.

20 No torreão da direita, "Coleções científicas, mineralógicas e geológicas", "Geologia econômica e indústria mineral", "Águas minerais, sal e salinas", "Pequena metalurgia”, "Borracha", "Substâncias taníferas, fibras e cascas industriais", "Frutos silvestres", "Mate”, “Óleos, ceras e resinas", "Madeiras", "Plantas medicinais", "Produtos de caça e pesca: peles brutas, penas, crinas e conchas"; no torreão central, "Sacas de café em pilhas", "Café em coco", "Café despolpado", "Tipos naturais", “Tipos de exportação", “Tipos de café estrangeiro", "Café torrado, em grão e moído", "Fotografias, estatísticas, diagramas e outros processos de demonstração"; no torreão da esquerda, "Açúcar", "Fumo", "Cacau", "Arroz, milho, trigo, cevada, centeio, feijão, alfafa, favas", "Produtos da zoologia agrícola", "Silvicultura, arboricultura, floricultura, fruticultura e horticultura". 
foi denominado Pavilhão de Honra, com esmerada decoração alusiva à República e também aos produtos em exibição, manufaturados e considerados mais nobres. Grandes painéis a óleo e estuque foram espalhados pelo edifício, também com motivos alegóricos. ${ }^{21}$ Por fim, o prédio da direita, com 1.936 metros quadrados, foi denominado Pavilhão Italiano e dedicado à colônia italiana do Brasil. Com dois pavimentos, quadrado, de decoração mais simples, mas também com muitas pinturas, sendo a principal uma alegoria a Annita e Giuseppe Garibaldi. Seria destinado a variados produtos manufaturados, da indústria da alimentação à construção civil. O segundo pavimento apresentaria uma série de dioramas, sem maiores informações sobre os temas, mas que deveriam ter "legendas sintéticas" para "salientar a situação econômica do Brasil, o seu progresso político-social e as suas garantias constitucionais", como por exemplo: "O Brasil é o maior produtor de café, mate, cacau e manganês"; "O Brasil, em extensão territorial, é o quarto país do globo e o mais vasto da América do Sul"; "No Brasil, todos são iguais perante a lei”. Espaço também foi reservado a um bureau de informações, distribuição de livros, postais e "publicações de propaganda".

Além dos edifícios, a seção brasileira também teria jardins com fontes iluminadas, plantados com espécies nativas; terraços, sob os quais seriam construídos "elegantes quiosques, destinados à degustação do café nacional"; e um pavilhão para o cinematógrafo, antes previsto para o Pavilhão Central, com sala para 350 pessoas e uma galeria reservada aos convidados. Ao todo, a área expositiva somava mais de 6.800 metros quadrados. Um exército de artistas e técnicos foi contratado para a decoração dos edifícios e das áreas externas, cujos trabalhos foram

21 Os painéis eram os seguintes: "Proclamação da República”, "o gênio latino", "a mata virgem, a derrubada, a queimada e as plantações", "Os Estados da República” e "Ordem e Progresso". Também havia um grande vitral, "A barra do Rio de Janeiro". As seções ali alocadas foram as seguintes: "Ensino primário, secundário, superior e técnico", "Coleções de numismática", "Arte musical", "Fotografia", "Tipografia e litografia, fototipia, fotogravura e outros processos de reprodução", "Papelaria e objetos de escritório: livros e publicações", "Medicina e cirurgia: artes farmacêuticas", "Saúde pública, assistência pública e particular", "Melhoramentos municipais", "Engenharia civil e militar", "Telegrafia e telefonia", "Relojoaria e ourivesaria”, "Pedras preciosas e semipreciosas", "Mobiliários de luxo". 
coordenados por 17 pessoas, algumas das quais renomados artistas brasileiros, homens e mulheres, como Antônio Parreiras, Carlos e Rodolpho Chambelland, Georgina de Albuquerque e Nicolina Vaz de Assis. ${ }^{22}$

Os problemas topográficos iniciais e o esmero na decoração dos edifícios tiveram consequências: apesar das promessas em contrário de Rezende e das advertências da comissão geral da exposição, os pavilhões brasileiros inauguraram com atraso. A mostra turinesa foi aberta solenemente em 29 de abril, com a presença de Vittorio Emanuele III e grande audiência estrangeira. A maioria dos pavilhões foi aberta no dia seguinte, inclusive o da Argentina, em prestigiada cerimônia oficial. ${ }^{23} \mathrm{O}$ público, contudo, só teve acesso à seção brasileira quase dois meses depois, gerando constrangimentos para os representantes do país. A julgar pelo relatório produzido pelos delegados paraenses, não houve sincronia entre as equipes responsáveis pela construção dos edifícios, pela remessa dos produtos e pela arrumação da mostra, assim como a concentração das atividades de remessa no Rio de Janeiro, sob a coordenação do Museu Comercial, produziu sobrecarga de trabalho no local e atrasos desnecessários, além de perdas e prejuízos com os sucessivos deslocamentos dos produtos. Os produtos brasileiros começaram a chegar em Turim somente no final de maio e foram ainda necessários vários dias para organizar a mostra, finalmente aberta em 23 de junho. No início de agosto, Rezende foi substituído por Costa Sena no Comissariado Geral. ${ }^{24}$

O detalhado relatório da delegação paraense também permite cotejar o que foi planejado por Rezende e o que foi possível realizar, sobretudo diante do atraso, da insuficiência de espaço para todos os expositores brasileiros inscritos na mostra, dos prejuízos no transporte do material e das condições limitadas de trabalho em Turim. Há, nesse relatório, uma evidente crítica ao trabalho feito pela comissão até então,

22 REZENDE, A. P. A. Relatorio..., p.93-102.

23 O JUBiLEU ITALIANO. O Estado de São Paulo (São Paulo), ano 38, n. 11.825, p.1, 01 maio 1911.

24 MARTINS, J. A. R.; ABREU, J. P. G.; HUBER, J. O Estado do Pará na Exposição Internacional das Indústrias e do Trabalho em Turim, 1911. Relatório apresentado ao Exmo. Sr. Dr. João Antonio Luiz Coelho, Governador do Estado, pela Delegação Paraense. Paris: Kauffmann, 1911. 
principalmente à falta de clareza na expografia e de coordenação das atividades. Segundo Martins et al., quando os representantes paraenses chegaram a Turim, em meados de abril, não havia "nenhum plano de organização das seções, nem se sabendo ao certo quais seriam os produtos ainda por chegar" ${ }^{55} \mathrm{Fez}$-se, então, uma "arrumação provisória" dos produtos que haviam sido exibidos na mostra de Bruxelas, em 1910, já transportados para a Itália. Coube a Abreu e Huber organizarem a seção de madeiras, trabalho que lhes tomou mais de 15 dias. Posteriormente, quando a maior parte dos produtos brasileiros já se encontrava em Turim, Abreu ficou responsável pela organização definitiva de todo o segundo pavimento do Pavilhão Italiano, que não recebeu os dioramas previstos por Rezende. Pelo contrário, ali foi exposta grande diversidade de produtos, arrumados com "dificuldades especiais" pela "falta de espaço e necessidade de desfazer-se uma parte dos mostruários provisórios para acomodar os novos produtos". Segundo os delegados paraenses, em razão do atraso na remessa dos produtos e da falta de organização prévia, mesmo depois de aberta ao público, a seção brasileira "teve de sofrer uma transformação quase completa, que aliás, com o concurso da boa vontade da maior parte dos nossos colegas, conduziu a um resultado melhor do que aquele que era de esperar". ${ }^{26}$ Curiosamente, uma das últimas seções a serem montadas foi a da borracha, justamente a que estava sob a responsabilidade dos paraenses. Segundo os delegados do estado, o atraso ocorreu porque nem todos os objetos foram enviados e porque os que estavam disponíveis chegaram tardiamente, entre eles, as amostras de borracha exibidas na Segunda Exposição Internacional da Borracha, realizada concomitantemente em Londres, de 24 de junho a 14 de julho, e na qual Huber também era representante oficial do Pará.

Além desses problemas, imprevistos se interpuseram diante da comissão brasileira, originados da interpretação do júri e do comissariado geral da mostra. Eles dizem respeito à classificação oficial dos produtos, "mais adaptada às condições dos países europeus do que às nossas”. Segundo

25 MARTINS, J. A. R.; ABREU, J. P. G.; HUBER, J. O Estado do Pará..., p.14.

26 MARTINS, J. A. R.; ABREU, J. P. G.; HUBER, J. O Estado do Pará..., p.17. 
Martins et al., "a classificação de certos produtos teve de ser modificada, às vezes repetidamente, sendo estes removidos de uma classe para outra e não poucas vezes de um grupo para outro". ${ }^{27}$ Os exemplos arrolados são suficientes para perceber modificações importantes nos planos de Rezende, como o caso da borracha. Os brasileiros classificaram-na nos grupos XV (silvicultura e indústria florestal) e XVIII (indústrias extrativas e químicas), mas o comissariado italiano entendeu que ela deveria ser classificada no grupo XXII, que fazia referência à indústria do couro e congêneres. Problema semelhante aconteceu com o cacau, classificado inicialmente no grupo de agricultura, depois transferido para a classe de confeitaria; e com as plantas medicinais, originalmente no grupo das indústrias extrativas e confirmadas na classe de produtos de grande cultura. Houve, ainda, casos de produtos brasileiros não aceitos por nenhum júri simplesmente porque tinham uma classificação incerta. Foi o que aconteceu com o óleo de copaíba enviado por farmacêuticos paraenses, rejeitado no grupo da indústria farmacêutica e também invisível para o das plantas medicinais. O fato gerou mais uma crítica dos representantes paraenses: em ocasiões futuras, o comissário geral deveria recorrer desde cedo aos organizadores da mostra para evitar as "incertezas". 28

Esses problemas dificultaram não apenas a organização do catálogo brasileiro e o trabalho do júri internacional, como também a própria concepção do espaço. Infelizmente, não foram encontrados croquis ou plantas baixas onde seja possível visualizar a proposta unificada de Rezende e nem a disposição final dos produtos, após a reformulação feita por Costa Sena. O relatório dos delegados paraenses fornece algumas pistas da mudança no projeto original ao informar que a maioria dos produtos do estado (florestais, agrícolas e alimentícios) foi exibida no Pavilhão Italiano e não no Pavilhão Central, como originalmente concebido, e que este último havia sido destinado às indústrias manufatureiras e ao café. Revela-se, portanto, uma inversão no uso dos edifícios e também uma interferência de ordem política na repartição do espaço,

27 MARTINS, J. A. R.; ABREU, J. P. G.; HUBER, J. O Estado do Pará..., p.21.

28 MARTINS, J. A. R.; ABREU, J. P. G.; HUBER, J. O Estado do Pará..., p.21. 
uma vez que isto teria acontecido em razão da "abundância" e da "boa qualidade" dos produtos paraenses e também da "incumbência que os delegados do Pará tiveram da organização de diversas seções”, acabando por privilegiar o estado no conjunto da mostra. ${ }^{29}$ Exemplos disso foram as duas telas expostas no vestíbulo do Pavilhão Central, adquiridas pelo presidente da delegação paraense, que ilustravam a coleta do látex e a defumação da borracha, pintadas, respectivamente, pelos brasileiros Francisco Machado e Carlos Seelinger. O local era privilegiado e, curiosamente, funcionava como antessala para a grande mostra de café. Outro exemplo foi o mostruário de madeiras amazônicas, enviado pelo Pará, exibido defronte da entrada principal do Pavilhão Italiano, juntamente com várias exsicatas do Museu Goeldi, que lhe faziam fundo e complementavam o arranjo com informações botânicas. O cenário sobressaía, portanto, diante dos mostruários enviados pelos demais estados (Figuras 3 e 4). Segundo Martins et al., o destaque foi dado pelo "aspecto deveras imponente" do mostruário paraense e por ser "a mais bela e a mais rica coleção de madeiras de toda a exposição". ${ }^{30}$

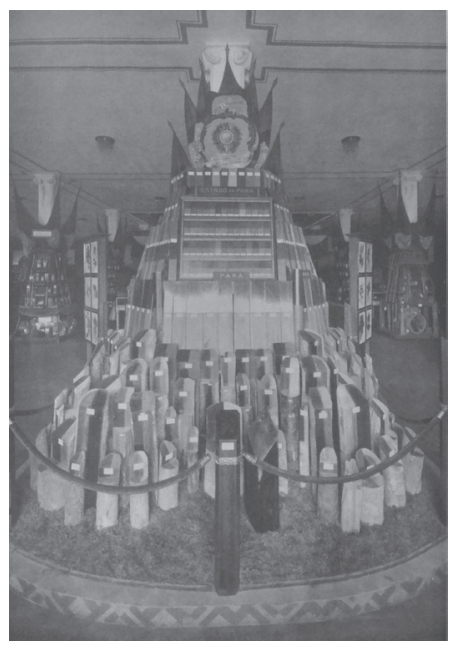

Figura 3. Fotografia publicada em Martins et al. (1911, p.19), com a seguinte legenda: "Pyramide de Madeiras do Pará, vista da entrada principal do $3^{\circ}$ Pavilhão. Exposição Internacional de Turim 1911”.

29 MARTINS, J. A. R.; ABREU, J. P. G.; HUBER, J. O Estado do Pará..., p.26.

30 MARTINS, J. A. R.; ABREU, J. P. G.; HUBER, J. O Estado do Pará..., p.26. 


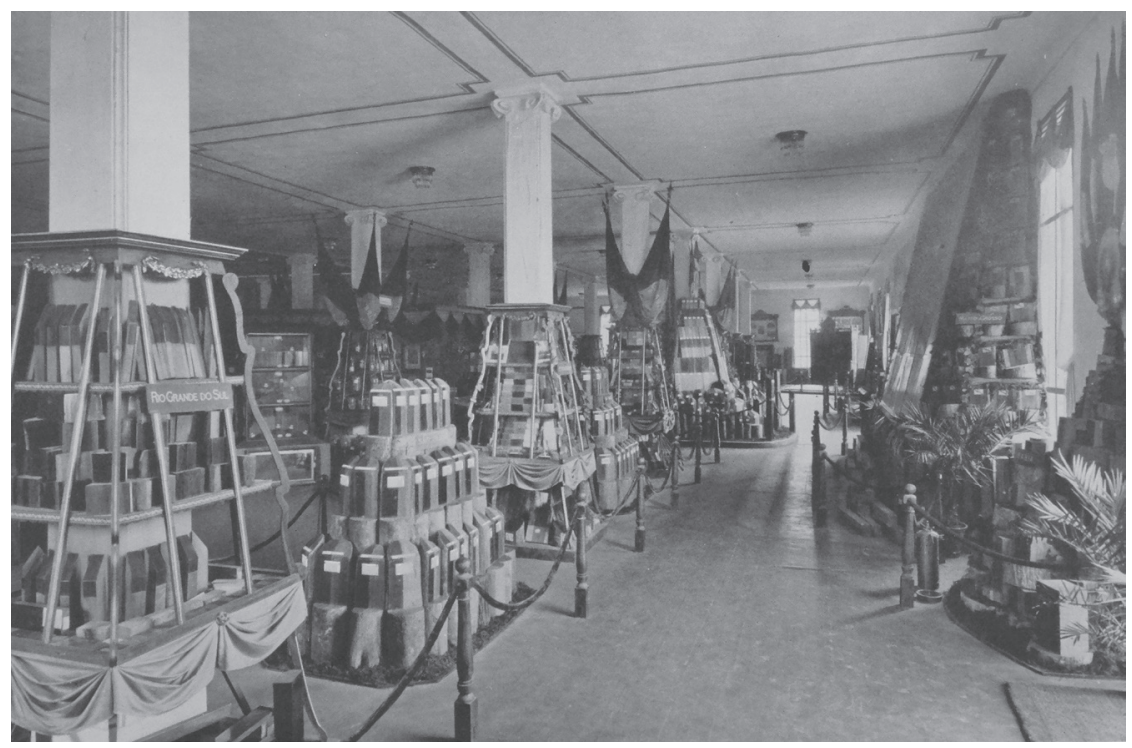

Figura 4. Fotografia publicada em Martins et al. (1911, p.15), com a seguinte legenda: "Aspecto geral da Secção das Madeiras do Brazil. (Organisado segundo o plano traçado pelos Delegados Paraenses). Exposição Internacional de Turim 1911".

Nenhum dos problemas aqui mencionados foi citado nos relatórios do Ministério da Agricultura, Indústria e Comércio. O relatório de 1910, sob o comando de Miranda, reproduz, sumariamente, as instruções publicadas no mesmo ano. ${ }^{31}$ Também relata as primeiras providências tomadas pelo ministro assim que foi confirmada a participação brasileira na mostra, como a concepção dos edifícios, sua ornamentação e a elaboração dos projetos executivos originais, aprovados em julho daquele ano. ${ }^{32}$ Em 1911, o novo ministro, Pedro de Toledo, limitou-se a reproduzir os planos de Rezende, acrescentando apenas que os Congressos de alguns poucos estados, entre eles São Paulo e Pará, haviam votado

31 MIRANDA, R. N. R. Relatório apresentado ao Presidente da República dos Estados Unidos do Brazil pelo Ministro de Estado da Agricultura, Indústria e Commercio, Rodolpho Nogueira da Rocha Miranda, no anno de 1910, Vol. 1. Rio de Janeiro: Officinas da Directoria Geral de Estatística, 1910, p.241-242.

32 MIRANDA, R. N. R. Relatório..., p.347-349. 
verbas especiais para a organização dos trabalhos locais e que haviam sido transportados para Turim 2.436 volumes, a um custo de mais de 574 contos-ouro, além dos volumes que seguiram diretamente do estado do Pará. ${ }^{33}$ Informações adicionais só apareceram no relatório de 1912, mais de um ano depois de encerrada a mostra. Por meio dele e do relatório dos delegados paraenses, é possível ter uma ideia mais clara da representação brasileira em Turim. Por exemplo, são feitas referências à realização de concertos, conferências e recepções no Pavilhão de Honra, e não no Pavilhão Central, como originalmente previsto; às mostras de minerais, rochas, têxteis, vestuário e café, organizadas no Pavilhão Central; e às variadas seções do Pavilhão Italiano, com destaque para as madeiras e a borracha, ambas no primeiro pavimento, sendo o stand da borracha acompanhado de um "riquíssimo mostruário de plantas do Amazonas e do Pará, sementes das árvores que a produzem e instrumentos empregados na extração do látex, tudo organizado debaixo do ponto de vista industrial e científico". Três dioramas também foram montados no primeiro pavimento (e não no segundo, como imaginado por Rezende), "representando panoramas do Amazonas, o preparo da terra para a plantação do café e a colheita deste produto". No segundo pavimento foram alocadas, entre outras, as seções de tabaco, açúcar, produtos alimentícios, estradas de ferro e portos. Nos quiosques de degustação, foi servida uma média de 6.000 xícaras diárias de café e mate, enquanto o cinematógrafo exibia, diariamente, variada programação de fitas "representando cidades, paisagens, fazendas de criação e de cultura, estradas de ferro, fábricas, estabelecimentos de ensino etc.". Em espaço contíguo, o público podia observar "o modo de torrar convenientemente o café". ${ }^{4}$

33 TOLEDO, P. Relatório apresentado ao Presidente da República dos Estados Unidos do Brazil pelo Ministro de Estado dos Negócios da Agricultura, Indústria e Commercio, Dr. Pedro de Toledo, no anno de 1911, Vol. 1. Rio de Janeiro: Officinas Directoria Geral de Estatística, 1911, p.323-325.

34 TOLEDO, P. Relatório apresentado ao Presidente da República dos Estados Unidos do Brazil pelo Dr. Pedro de Toledo, Ministro de Estado da Agricultura, Indústria e Commercio, no anno de 1912, Vol. 1. Rio de Janeiro: Imprensa Nacional, 1912, p.244. 
Pode-se concluir que, entre o planejado e o realizado, houve uma mudança na concepção dos pavilhões. O maior deles, por exemplo, deveria homenagear a colônia italiana no Brasil não apenas no nome, mas também na exibição de produtos manufaturados por famílias provenientes da Itália, conforme imaginou Miranda, mas assumiu nova configuração graças aos delegados paraenses, que deram destaque aos produtos amazônicos. O resultado não deixa de ser surpreendente, pois a borracha e as madeiras sequer foram mencionadas em documentos do Ministério até a publicação do segundo relatório de Toledo em 1912, mesmo sendo a borracha o segundo item no quadro de commodities brasileiras e mesmo que estivesse enfrentando, assim como o café, grave crise de produção e a Itália despontasse como excelente alternativa ao monopólio comercial inglês. Outra evidente conclusão é que as mudanças e os percalços durante a organização da seção brasileira são perceptíveis apenas quando as fontes oriundas do governo federal são cotejadas e complementadas com outras fontes, como o relatório dos delegados paraenses. É possível que a compreensão desse processo seja ampliada à medida que novas fontes sejam descobertas e incorporadas em futuras análises, sobretudo as originadas de governos estaduais, de associações comerciais e de particulares. Restam muitas perguntas relacionadas aos pavilhões, como o lugar do café, do açúcar e dos minerais, produtos associados a poderosos lobbies e interesses, bem como a identidade das pessoas que tomaram a decisão do quê, como e onde expor, ou ainda o que foi considerado importante do ponto de vista político-econômico e digno de ser exibido do ponto de vista estético. O fato é que, pela insuficiência de investigação, não se sabe, até o momento, a real dimensão da mostra brasileira em Turim e nem como o espaço foi aproveitado, isto é, quais os critérios (classificatórios, estéticos, políticos etc.) utilizados para distribuir e arrumar, na área expositiva, os produtos enviados por mais de três mil expositores. As várias fontes existentes certamente serão úteis àqueles que se dispuserem a realizar tal análise. 


\section{ProgresSo E MOdERNIDADE: UMA INDÚSTRIA PARAENSE?}

Apesar das dificuldades enfrentadas pela comissão brasileira, o 'sucesso' da mostra foi exaltado em vários documentos, que se referem à farta distribuição de publicações e ao grande número de visitantes, alguns bastante ilustres, como a rainha Margherita de Saboia, o presidente do Conselho de Ministros, os presidentes do Comitê Geral e da Comissão Executiva da Exposição e várias autoridades italianas. Segundo Martins et al., a mostra brasileira foi visitada por 241.000 pessoas, sendo a de "maior frequência de toda a exposição" ${ }^{35} \mathrm{O}$ número apresentado é bastante significativo, pois o público contabilizado nos 200 dias da exposição turinesa foi de 7.409.145 pessoas. Segundo Toledo, o Brasil ficou em terceira posição quanto ao número de expositores e de prêmios obtidos. ${ }^{36}$ No total, foram 3.204, entre os quais quatro Hors Concours (de qualidade excepcional e fora da competição), 192 Grandes Prêmios, 228 Diplomas de Honra e 715 Medalhas de Ouro. ${ }^{37}$

O Pará participou da mostra com 126 expositores e foi agraciado com 255 prêmios, sendo 12 Grandes Prêmios, 17 Diplomas de Honra e 80 Medalhas de Ouro. Ficou em quarto lugar no cômputo geral da seção brasileira, atrás de São Paulo, Minas Gerais e Pernambuco. Este foi o melhor desempenho do estado em exposições internacionais, bem superior ao obtido nas mostras de Saint Louis (1904), onde 17 expositores angariaram 18 prêmios, e de Bruxelas (1910), com 33 expositores e 66 prêmios. Além disso, o estado recebeu um dos quatro prêmios Hors Concours conferidos ao Brasil, destinado a Jacques Huber pelos trabalhos sobre a borracha amazônica. ${ }^{38}$ Segundo Martins et al., a mostra turinesa foi “a primeira exposição internacional em que o Pará se fez

35 MARTINS, J. A. R.; ABREU, J. P. G.; HUBER, J. O Estado do Pará..., p.18.

36 TOLEDO, P. Relatório...

37 Ver a relação completa em BRASIL. Relação dos Expositores Brazileiros Premiados. [Rio de Janeiro]: Commissariado Geral do Brazil na Exposição Internacional de Turim, 1911, 1912.

38 Os outros distinguidos com a honraria foram Apollônio Peres, de Pernambuco, pelos trabalhos sobre a indústria açucareira, Pio Rossi e A. Câmara \& Cia., ambos do Distrito Federal. 
representar condignamente, (...) não só pelo número de expositores e a excelência dos seus produtos, como pela apresentação do seu mostruário". ${ }^{39} \mathrm{Na}$ avaliação dos delegados paraenses, em Turim o estado teve um "real destaque" no conjunto da seção brasileira, ao contrário do que acontecera em Bruxelas, onde os produtos do Pará, apesar de sua "regular quantidade" e "boa qualidade", não foram priorizados "devido a ser o espaço insuficiente para a separação dos produtos segundo a sua procedência". 40

Cabe perguntar, para além dos números e da disputa entre as unidades federativas brasileiras, quais foram os produtos paraenses expostos, os premiados e quem eram os responsáveis por eles. Segundo Martins et al., o estado participou de 12 grupos, entre os 26 existentes. ${ }^{41}$ A maioria dos expositores (33\%) participou da classe 80 (governo das florestas e produtos florestais) do grupo XV (silvicultura e indústrias florestais), principalmente com madeiras e fibras. O segundo maior grupo (18\%) foi alocado na classe 90 (produtos de grande cultura) do grupo XVI (agricultura), exibindo, sobretudo, plantas medicinais, as quais, no entendimento dos delegados paraenses, eram produtos do extrativismo. O terceiro grupo (16\%) pertencia à classe 141 (borracha) do grupo XXII (indústria do couro e congêneres), sobretudo com amostras de borracha, aí classificadas pelo júri internacional certamente em razão das aplicações industriais do látex, que estava substituindo o couro como principal revestimento impermeabilizante de roupas, calçados e instrumentos. No total, $67 \%$ dos expositores estavam ligados, diretamente, ao extrativismo vegetal, incluindo a borracha. Se as peles de animais silvestres (classe 81 do grupo XV) e os minerais (classes 106, 110 e 113 do grupo XVIII) forem considerados, o número sobe para 91\%, demonstrando

39 MARTINS, J. A. R.; ABREU, J. P. G.; HUBER, J. O Estado do Pará..., p.57.

40 MARTINS, J. A. R.; ABREU, J. P. G.; HUBER, J. O Estado do Pará..., p.57.

41 Os grupos com participação paraense foram: Educação e ensino profissional; A fotografia e as suas aplicações; Navegação; A cidade moderna; Decoração e mobiliário das casas; Silvicultura e indústrias florestais; Agricultura; Indústria de produtos alimentícios; Indústrias extrativas e químicas; Indústrias do vestuário e da toilette; Indústria do couro e congêneres; Colonização e emigração. 
que a grande maioria dos produtos exibidos pelo Pará era de origem extrativista. A pequena indústria de transformação existente no Pará, como a de mobiliário, vestuário, alimentação, farmacêutica, perfumaria e química estava pouco representada.

De acordo com Martins et al., foi possível dividir os expositores paraenses em três categorias: os municípios, em número de 22, que apresentaram principalmente produtos da indústria extrativa, da pequena indústria florestal e da agricultura, incluindo farináceos e tabaco; os "particulares do interior", com produtos da mesma natureza; e os da capital, que se fizeram representar com produtos da indústria manufatureira, alimentícios e farmacêuticos. ${ }^{42}$ É possível identificar, ainda, um quarto grupo, formado por instituições governamentais do estado, que exibiram produtos sortidos, de toras de madeira a fotografias. $\mathrm{Na}$ classe 80 , que reuniu o maior número de expositores, foram 41 prêmios, angariados principalmente pelas intendências municipais e pelos particulares do interior. Na classe 90, o segundo maior grupo, foram 23 prêmios, divididos também entre as intendências e os particulares do interior. Na classe 141, a da borracha, 20 prêmios - incluindo um Hors Concours (Jacques Huber), um Grande Prêmio (coleção de borrachas do Governo do Estado), um Diploma de Honra (herbário e fotografias do Museu Goeldi) e dez Medalhas de Ouro - foram partilhados pelas intendências, por particulares da capital e pelo governo estadual. No conjunto, percebe-se uma divisão na atribuição dos prêmios, ficando os produtos manufaturados, sobretudo alimentícios e farmacêuticos, com empresas ou particulares da capital.

A razão dessa divisão é simples: a formação econômico-social do Pará foi baseada quase que exclusivamente em atividades extrativas primárias. Somente na segunda metade do século XIX houve algum incremento nas indústrias de transformação, constituídas a partir de capital empresarial, associado à mão-de-obra assalariada, ao uso de máquinas e ferramentas, portanto, com emprego de tecnologia, mesmo que não fosse a mais avançada. Em grande maioria, eram fábricas de

42 MARTINS, J. A. R.; ABREU, J. P. G.; HUBER, J. O Estado do Paráa.., p.21. 
bens de consumo não duráveis, localizadas nas maiores cidades. São os casos das fábricas Palmeira, fundada em 1892 e na qual 400 operários produziam pães, doces, açúcar refinado e café moído, e de Cerveja Paraense, de 1905 e que empregou 150 operários na produção de cervejas e refrigerantes com maquinário alemão (Mourão, 1989). Ambas estavam representadas em Turim e foram premiadas, a primeira com uma Medalha de Ouro e a segunda com um Grande Prêmio, mas suas amostras eram modestas e poderiam ter recebido maior destaque, conforme avaliaram os próprios delegados paraenses. ${ }^{43}$

No programa da exposição turinesa, a agricultura e o extrativismo (animal, vegetal e mineral) foram considerados indústrias, no sentido de serem ocupações humanas e atividades econômicas básicas para o processo industrial. Contudo, esse conceito ampliado não escondia uma hierarquia econômica. Em uma feira internacional que deu destaque às aplicações da eletricidade - de trens a baterias recarregáveis - e também ao automobilismo e à aeronáutica, a mostra paraense contribuía para colocar o Brasil em uma posição inferior entre as nações industrializadas, como produtor de matérias-primas sem nenhum tipo de processamento ou com manufatura primária. Ela também refletia, com notável precisão, a estrutura da economia amazônica no início do século XX, refém das casas aviadoras e das grandes companhias de exportação e importação, sobretudo inglesas, que impediam, na prática, o desenvolvimento da indústria de transformação. O capital gerado na Amazônia com a exportação da borracha bruta não era reinvestido no aperfeiçoamento do extrativismo ou em plantations, como ingleses e holandeses vinham fazendo no Oriente desde a década de 1870. Esse capital sequer permanecia na região, sendo drenado, na forma de juros e bens de consumo importados, para as indústrias e os grandes bancos europeus (Santos, 1980; Loureiro, 2008).

No início do século XX, a percepção desse problema estrutural era limitada. Sabia-se que a indústria paraense era pequena quando comparada com outras regiões brasileiras, e mais ainda se confrontada com os países

43 MARTINS, J. A. R.; ABREU, J. P. G.; HUBER, J. O Estado do Pará... 
europeus. Mas acreditava-se que, no liberalismo característico do século XIX, haveria um lugar permanente no sistema econômico para as nações produtoras de matérias-primas - e que a industrialização dessas nações era uma questão de tempo, desde que ficasse demonstrado o potencial dos recursos naturais disponíveis. Isso o Brasil e o estado Pará tinham de sobra, razão pela qual o investimento dos poderes públicos concentrava-se na propaganda desses recursos, ressaltando-lhes as "qualidades insuperáveis”, fossem café, borracha, açúcar, madeira ou fibras.

A propaganda das riquezas naturais do estado era o objetivo principal da comissão responsável pela representação do Pará na exposição turinesa. Além dela, conviria demonstrar o "grau de adiantamento" das indústrias locais, pois estas poderiam se desenvolver a partir das relações comerciais com a Itália. Em carta circular expedida aos possíveis expositores, em 19 de julho de 1910, a comissão deixou clara sua preocupação com a impressão que a mostra deixaria nos visitantes, sobretudo nos anfitriões italianos. Era desejo do governador, dizia a carta, "dar à representação paraense um desenvolvimento digno da grandeza desta terra". ${ }^{44}$ Para tanto, foi criada uma grande comissão, composta por 29 membros, entre os quais grandes comerciantes de borracha, fazendeiros, empresários e engenheiros. A presidência foi conferida a Innocêncio Hollanda de Lima, secretário das Obras Públicas, Terras e Viação, e a vice-presidência, a Inácio de Sousa Lages, de família paraense residente em Lisboa, feito Barão pelo rei de Portugal, Carlos I. Jacques Huber aparece em quinto lugar na lista, logo abaixo do primeiro e do segundo secretário, e parece ter sido um dos mais ativos membros do grupo. Foi nomeado para a subcomissão de "arrecadação dos produtos" 45 e redigiu tanto a carta circular aos possíveis expositores, já citada, quanto as

44 Carta Circular sobre a Exposição Internacional das Indústrias e do Trabalho em Turim 1911. Belém, 19 jul. 1910. Impresso. Museu Paraense Emílio Goeldi, Arquivo Guilherme de La Penha, Fundo Museu Paraense, Gestão Jacques Huber, Série Congressos e Exposições (doravante, MPEG/AGLP).

45 Ofício de Innocêncio Hollanda de Lima, Secretário de Estado das Obras Públicas, Terras e Viação, a Jacques Huber, Diretor do Museu Goeldi. Belém, 30 maio 1910. Datiloscrito. MPEG/ AGLP. 
"Instruções preliminares para a escolha dos produtos destinados à Exposição de Turim (1911)". ${ }^{46}$ Segundo esse documento, a seção paraense deveria apresentar três categorias de produtos: a primeira e principal seria formada por "boas amostras de todos os produtos que atualmente se exportam para a Europa e cuja exportação convém desenvolver, como borracha, castanha, cacau, cumaru, madeiras, óleo de copaíba, plantas medicinais, peles de veado e de outros animais, grude de peixe etc." (grifo do original); a segunda, por "produtos que, apesar de ainda não exportados para a Europa, poderiam ser produzidos em quantidade suficiente para este fim", como cascas taníferas, fibras, painas, óleos, resinas e ceras vegetais, além de produtos agrícolas, farinha e alimentos em conserva; a terceira, por "produtos industriais que, apesar de não serem destinados à exportação, mostram, entretanto, o adiantamento do país e podem chamar o estabelecimento de indústrias congêneres e a afluência de imigrantes espontâneos", além de publicações, fotografias e quadros estatísticos que pudessem dar "uma ideia das condições gerais do país e do seu grau de civilização".

A ênfase dada ao extrativismo na mostra paraense tinha, como se percebe, razões econômicas, assim como a pequena participação das indústrias de transformação estava prevista desde o início, ali presentes muito mais como ilustração do que como atividade econômica significativa para o estado. As "Instruções..." de Huber já continham, portanto, as ideias básicas que dariam forma à mostra paraense em Turim e que espelhavam, com bastante precisão, a estrutura econômica da Amazônia no início do século XX.

As reuniões da comissão paraense tiveram início em junho de 1910 e prosseguiram com frequência quinzenal. Nos encontros eram discutidos o formato da exibição, o levantamento e a seleção dos produtos a serem levados para a Itália, o transporte desses produtos até Belém e dos delegados em direção ao Rio de Janeiro e à Europa, o material de divulgação a ser produzido, entre outros preparativos. Duas frentes de

46 "Instruções preliminares para a escolha dos produtos destinados à Exposição de Turim (1911)”. Datiloscrito. MPEG/AGLP. 
trabalho paralelas foram organizadas, a de seleção dos produtos e a de navegação e transporte. Ambas as frentes atuavam em conjunto com as comissões formadas em cada município, das quais participavam, além do intendente, comerciantes locais, proprietários de terras e moradores que produzissem algo considerado interessante. Essas comissões municipais tinham como tarefa a arrecadação de produtos, obedecendo aos critérios da categoria na qual pretendiam concorrer, e a remessa para a comissão da capital, responsável pela seleção do que iria figurar em Turim. Simultaneamente, o governador João Coelho encarregava-se de obter créditos junto ao Congresso Estadual e o necessário apoio dos intendentes municipais, convidados a trabalhar com "solicitude e zelo para que os produtos angariados não contrastem com as intenções do governo, de modo a ter a representação do vosso município uma feição sobretudo prática". ${ }^{47}$ Com o termo "feição prática" o governador salientava que somente produtos de boa qualidade e que pudessem ser comercializados deveriam ser enviados, de modo que a seção paraense em Turim fosse um "preconício prático e sério do nosso desenvolvimento intelectual e material, de preferência a uma ostentação platônica e estéril, que não resulte frutuosa para o Estado e compensadora dos dispêndios que se torna mister fazer" ${ }^{48}$

A preocupação em mostrar um Pará material e intelectualmente desenvolvido era sempre enfatizada nas reuniões da comissão, fosse por meio da seleção de bons produtos e de sua apresentação condigna, fosse por meio de impressos, fotografias e fitas cinematográficas a serem produzidos especialmente para a mostra turinesa. Por exemplo, na reunião de $1^{\circ}$ de outubro de 1910, foi discutida, entre outros assuntos, a confecção de fitas cinematográficas, por proposição de Huber. Segundo o jornal Folha do Norte, que regularmente publicava o dia, a hora, o local e a ata das reuniões, Huber leu "uma relação das vistas que se tem de

47 COELHO, J. A. L. Mensagem dirigida em 7 de setembro de 1910 ao Congresso Legislativo do Pará pelo Dr. João Antonio Luiz Coelho, Governador do Estado. Belém: Imprensa Official do Estado do Pará, 1910, p.42.

48 COELHO, J. A. L. Mensagem..., p.41. 
apanhar, no interior e na capital, com os aspectos da nossa vida comercial e fluvial, e de cuja confecção declarou incumbir-se o sr. O’Neill, representante da casa Slig [sic], de Nova Iorque" ${ }^{49}$ Os roteiros dessas fitas foram, felizmente, preservados. Seriam seis, medindo de 500 a 1000 pés de comprimento: "Movimento do porto e das ruas da capital", "Serviço de profilaxia da febre amarela", "Indústria e comércio da borracha", "Cenas da indústria pastoril em Marajó e no Baixo Amazonas", "Viagem na Estrada de Ferro de Bragança" e "Cultura, colheita e preparo do cacau".50 Destas, somente três foram efetivamente contratadas ao cinegrafista a um custo de dois contos de réis cada uma: "Movimento do porto de Belém", focando a carga e descarga, o trânsito de passageiros, a construção do novo porto e o embarque da borracha; "Serviço de profilaxia da febre amarela", com imagens do depósito de material, do expurgo de casas, vapores e esgotos, do controle de focos de mosquitos, do trabalho de laboratório e do transporte de "amarelentos"; e "Cultura, colheita e preparo do cacau", com o registro de viveiros e plantações, colheita e abertura dos frutos, "trabalho com o tipiti", fermentação, secagem e ensacamento. $\mathrm{O}$ contrato, assim como os roteiros, foi redigido por Huber e assinado em 18 de janeiro de 1911 pelo presidente da comissão paraense e por Emmet Vincent O’Neill, apresentado como cidadão norte-americano e representante da Selig Polyscope Co., de Chicago. ${ }^{51}$

As fitas encomendadas, das seis propostas por Huber, ilustram bem as preocupações da comissão paraense. Na primeira delas, houve uma alteração no roteiro original, com a eliminação das imagens dos mercados do Ver-o-Peso e de Ferro, dos "carros elétricos", do bairro comercial, das

49 O PARÁ EM TURIM. Folha do Norte (Belém), n. 4643, p.1, 01 out. 1910.

50 "Fitas cinematográficas (especificações)", sem data. Manuscrito. MPEG/AGLP.

51 “Contrato". Pará, 18 de janeiro de 1911. Datiloscrito. MPEG/AGLP. William Selig, fundador da Selig Polyscope Company em 1896, é considerado "o homem que inventou Hollywood". Fundou seu estúdio em Chicago, mas o transferiu para Los Angeles em 1909 para escapar da batalha judicial promovida por Thomas Edison contra os produtores de filme independentes. O’Neill foi um dos cinegrafistas de uma famosa fita, na qual Selig reproduziu, em estúdio, o safári que Theodore Roosevelt fez na África (Cf. ERISH, 2012). O trabalho de O'Neill em Belém ainda não foi investigado. Não há menção às fitas no relatório dos delegados paraenses. 
largas avenidas, da revista militar, do Palácio do Governo e da "festa de Nazareth", focando-se apenas o porto de Belém - signo maior do desenvolvimento da cidade. Na época, era intenso o movimento de produtos importados e de borracha, que seguia, sobretudo, para os Estados Unidos e a Inglaterra. Rotas transatlânticas ligavam Belém a Nova Iorque e aos principais portos europeus, excetuando os italianos, sendo possível também atingir, via Recife, Salvador e Rio de Janeiro, as cidades de Dakar e Buenos Aires. Ao mesmo tempo, rotas fluviais ligavam Belém a todos os rios da bacia amazônica, com conexões em Manaus e Iquitos. Em 1911, o porto da cidade, administrado por companhia inglesa, passava por grande transformação, com a ampliação do deck, construção de novos galpões e modernização do maquinário.

O corolário de que a cidade gozava do desenvolvimento material e intelectual seria exibido na segunda fita, sobre o serviço de profilaxia da febre amarela, cujo roteiro contratado foi mantido tal como Huber planejara. A iniciativa foi considerada a maior contribuição do governador João Coelho, que contratou Oswaldo Cruz e mais dez sanitaristas para coordenarem o serviço, replicando na cidade o trabalho antes executado no Rio de Janeiro. O expurgo das instalações urbanas e a eliminação dos focos de mosquitos foram realizados a partir de novembro de 1910, sendo Belém declarada livre da doença um ano depois (Rangel, 2010; Fraiha Neto, 2012). Com um porto moderno e uma cidade salubre, estaria desimpedido o caminho para os imigrantes estrangeiros e garantidas as condições para a instalação de empresas em Belém. Ambas as fitas demonstravam a responsabilidade do Estado em relação aos investimentos necessários ao progresso.

$\mathrm{Na}$ sequência, a terceira fita apresentava um negócio alternativo à exportação de borracha, cujo roteiro de Huber também foi mantido no contrato, sem alterações. O cacau era, juntamente com a castanhado-pará, o produto com maior potencial de exportação no estado. $\mathrm{O}$ próprio Huber já havia sugerido incentivar o plantio de cacau de maneira a tornar a economia amazônica menos dependente da borracha. O plantio poderia ser feito de maneira consorciada com a seringueira, 
esta, árvore mais alta e provedora da sombra exigida pelos cacaueiros. ${ }^{52}$ As extensas e antigas plantações de cacau no baixo Amazonas e no rio Tocantins, onde algumas empresas de capital estrangeiro já operavam, poderiam, segundo Huber, servir como áreas piloto para a conversão da economia amazônica, do extrativismo para a agricultura consorciada. Cabia aperfeiçoar as formas de plantio e combater os problemas fitossanitários, razões para a criação de um Serviço de Assistência aos Plantadores de Cacau, efetivamente criado pelo governo paraense, em 1913, por proposição de Huber..$^{53}$

A par dos significados do cinema nas exposições internacionais, como signo do avanço tecnológico e do testemunho documental, mas também da ilusão e do mundo imaginado, convém indagar sobre as fitas planejadas por Huber, mas não contratadas pelo governo do Pará. A principal delas previa uma sequência de imagens que deveria representar todo o processo de produção primária da borracha, com todos os seus agentes sociais, desde a saída do seringueiro rumo ao trabalho, continuando com o corte da seringueira, a coleta do látex, a defumação, a pesagem e o embarque da borracha no seringal, o corte e encaixotamento da borracha, o transporte para o porto de Belém e o embarque para exportação. As imagens finais deveriam ser feitas em uma plantação de seringueiras, sugerindo que o processo estava em transformação e que a região amazônica também modernizava seus modos de produção. A outra fita deveria ser rodada no Marajó e exibir as fazendas do rio Arari, a 'malhada', o 'ferro' e o embarque do gado, as diversas raças criadas, a matança de jacarés e capivaras, a pesca e outros aspectos da vida animal.

52 HUBER, J. O Cacao, por F. Simão da Costa. Segunda edição augmentada e organisada por ordem do Exm. Dr. Augusto Montenegro, Governador do Estado, pelo Dr. J. Huber. Pará: Typ. e Encadernação do Instituto Lauro Sodré, 1908.

53 HUBER, J. "These IV - A Cultura do Cacau. Necessidade de sua reorganização em todo o Estado. Importância do beneficiamento", jul. 1913. Manuscrito. MPEG/AGLP; HUBER, J. "Instruções para o serviço de assistência aos plantadores de cacao no Rio Tocantins", 20 nov. 1913. Manuscrito. Museu Paraense Emílio Goeldi, Arquivo Guilherme de La Penha, Fundo Museu Paraense, Gestão Jacques Huber, Série Trabalhos Técnicos. 
A terceira fita faria uma viagem pela Estrada de Ferro de Bragança, em cujas margens implantava-se um grande projeto de assentamento de colonos para a produção agrícola e o abastecimento de Belém. Deveriam ser filmados o movimento das estações, o Instituto do Prata (missão religiosa onde viviam índios Tembé) e a Estação Experimental Agrícola. A fita encerraria com a cidade de Bragança e seus arredores, na época importante centro de produção de farinha de mandioca e tabaco.

O projeto das seis fitas cinematográficas, se cotejado com o que foi exibido em Turim pelos expositores paraenses, era absolutamente coerente. Se todas tivessem sido rodadas, estariam representadas as principais atividades econômicas do Pará, com seus agentes sociais e produtos. Seria possível ver como eram produzidos os artefatos expostos nos pavilhões brasileiros, a infraestrutura e os modos de produção, as condições de trabalho e as categorias de trabalhadores. Contudo, o que parecia interessante ou atraente para um suíço, como o registro de seringueiros em ação e da matança de jacarés e capivaras no Marajó, não o era para os demais membros da comissão, incluindo seus vários fazendeiros. As três fitas eliminadas exibiriam o que existia de mais primitivo na economia amazônica, fosse o modo de coleta do látex, a pecuária marajoara, a pesca artesanal ou as reais condições de vida dos colonos assentados ao longo da estrada de ferro, onde grassava a malária, para não falar de índios aldeados por missionários. Essas imagens certamente exporiam as contradições da propaganda governamental, as desigualdades sociais, as fragilidades políticas da democracia brasileira e, sobretudo, a precariedade das bases sobre as quais a economia amazônica erguia-se, e que se esfumariam logo após a mostra de Turim. Ao não registrar a labuta diária das pessoas, suas condições de vida e de trabalho, eliminava-se a possibilidade de gerar efeitos adversos ante as intenções propagandistas do governo. Nada deveria parecer exótico, rústico ou atrasado. Portanto, deveria ser filmado apenas o movimento do porto, que não permitia acessar maiores informações sobre a economia local, a ação de cientistas e sanitaristas para melhorar a vida na capital e uma oportunidade para 
negócios. Dessa maneira, o cenário restaria convidativo a um público que se permitia iludir pelo cinema. ${ }^{54}$

Outro material propagandístico gestado pela comissão paraense, para ser distribuído em Turim, reiterava a mensagem das fitas cinematográficas. Trata-se do livreto Lo Stato del Pará (Brasile) a Torino 1911, impresso em Turim também com uma versão em francês. Ele apresenta um conjunto de textos sobre assuntos diversos sem uma ordem aparente, sem introdução e sem créditos. O primeiro deles discorre sobre o "movimento artístico do Pará" após a Proclamação da República, que o teria colocado em "terceiro lugar entre os estados brasileiros mais avançados em termos artísticos" ${ }^{55}$ Nesse texto desfilam os principais pintores, escultores, arquitetos e músicos contratados pelo governo e por particulares, bem como são arrolados os principais acervos e edificações existentes na capital, com a intenção de demonstrar que "o progresso estético da capital do estado segue concomitante aos mais notáveis melhoramentos, os quais doravante colocam Belém ao nível das cidades mais avançadas do continente americano". ${ }^{56}$ Seguem-se informações sobre a situação econômica e financeira do estado, com tabelas e quadros da produção, exportação, receita e câmbio, alguns bastante detalhados e com séries históricas que demonstram o incremento econômico do Pará desde a década de 1890. A navegação é apresentada em detalhe, com a lista das empresas que atuavam no estado, dos batelões e vapores que percorriam cada uma das rotas, sua capacidade de passageiros e de carga, a frequência das viagens, o preço das passagens e do frete e ainda um mapa encartado onde aparecem as rotas transoceânicas e os portos

54 A apresentação de fitas cinematográficas no pavilhão brasileiro em Turim vale uma investigação à parte, tal como Morettin vem realizando para outras exposições (ver MORETTIN, 2011a, 2011b, 2012, 2013). Não se conhece ainda quais filmes foram exibidos, quem foi responsável pela produção, qual a reação do público e da imprensa e se sobreviveram ao tempo. No caso dos filmes contratados pelo governo do Pará a O’Neill, ainda não há confirmação se foram, efetivamente, rodados e exibidos em Turim.

55 LO STATO DEL PARÁ (BRASILE) A TORINO 1911. Torino: Denina, 1911, p.5.

56 LO STATO DEL PARÁ..., p.11-12. 
conectados a Belém. Uma longa seção apresenta a produção e o preço de cada uma das commodities paraenses, os bancos e estabelecimentos de crédito e a legislação para o comércio exterior. Em seguida, um texto sobre o cultivo da seringueira apresenta dados superdimensionados sobre as plantações então existentes no Pará. Segundo o texto, "a Amazônia é a melhor região do mundo para a grande e remuneradora cultura da seringueira e do cacau, e nenhum outro lugar poderá ser comparado a ela em fertilidade da terra, condições favoráveis do clima (...), potencialidade de produção e qualidade do produto.". $\mathrm{O}$ apoio estatal aos grandes plantadores seria garantido por uma nova lei de acesso à terra, promulgada em 1909 e transcrita no livro, que não apenas liberava as glebas devolutas à iniciativa privada como também facilitava a compra, a venda e o registro de imóveis, bem como isentava de obrigações fiscais os empreendimentos latifundiários. O livro finaliza descrevendo como era realizado o cultivo do tabaco nos municípios do leste paraense, certamente visando o mercado italiano, grande produtor e consumidor de cigarros, a ponto de justificar, na exposição turinesa, a existência de um Pavilhão do Tabaco.

O livreto reunia um conjunto de informações práticas para quem estivesse interessado em migrar ou investir no Pará. De acordo com as intenções do governador, a ideia era "estimular um comércio novo que nos traria nova fonte de receita" e promover uma "expansão mercantil" na Itália. ${ }^{58}$ Tanto os produtos selecionados para a exposição quanto o material propagandístico do estado guardavam coerência com esse duplo compromisso, o de diversificar a pauta de exportações paraenses por meio da promoção de vários produtos do extrativismo (lembramos que somente $16 \%$ dos expositores paraenses estavam ligados à exportação de borracha) e o de diversificar o mercado consumidor por meio da abertura de negócios diretamente com a Itália, grande consumidora de matérias primas, mas dependente das intermediações feitas pela Inglaterra. A expografia do pavilhão brasileiro (o Italiano) seguiu o mesmo

57 LO STATO DEL PARÁ..., p.72.

58 COELHO, J. A. L. Mensagem..., p.42. 
princípio, apontando para a qualidade e a diversidade dos produtos paraenses, como demonstram as seções de borracha, madeira e fibras. As três tiveram um destaque similar em termos de espaço e mobiliário, sendo concebidas como "mostruários" comerciais e não como "meras instalações decorativas", como recomendou o governador. ${ }^{59}$ Concomitantemente, os delegados paraenses agiam em duas frentes diplomáticas, a primeira para dar credibilidade aos produtos amazônicos, sobretudo a borracha, cujo comércio estava gravemente ameaçado pelos plantadores ingleses e holandeses no Oriente, e a segunda para viabilizar as transações com a Itália por meio da abertura de uma linha de navegação entre Gênova e Belém. Ambas as frentes, como se verá, estavam associadas - e para ambas a presença de Huber era fundamental.

\section{REFERÊNCIAS BIBLIOGRÁFICAS}

ANDERMANN, Jens. Espetáculos da diferença: a Exposição Antropológica Brasileira de 1882. Topoi, vol. 5, n. 2, p.128-170, 2004.

ANDERMANN, Jens. The Optic of the State: visuality and power in Argentina and Brazil. Pittsburgh: University of Pittsburgh Press, 2007.

BALOCCO, Piergiorgio. L'Esposizione Internazionale di Torino del 1911. Turim: Graphot, 2011.

BASSIGNANA, Pier Luigi. Torino effimera: due secoli di grandi eventi. Turim: Edizioni del Capricorno, 2006.

BIBLIOTECHE CIVICHE TORINESE. Le esposizioni torinesi. Cittá di Torino, 2006. Disponível em: http://www.comune.torino.it/cultura/biblioteche/ricerche_cataloghi/pdf/bibliografie/esposizioni.pdf; Acesso em: 08 abr. 2015.

BURKE, Bridget; SERAFICA, Cathy; HIGGINS, Martha. Revisiting the World's Fairs and International Expositions: a selected bibliography, 1992-2004. Smithsonian Institution Libraries, 2005. Disponível em: http://www.sil.si.edu/silpublications/Worlds-Fairs/introduction.htm; Acesso em: 08 abr. 2015.

59 COELHO, J. A. L. Mensagem..., p.42. 
CASTRO, Anna Raquel de Matos. Do ponto de vista do cientista: Jacques Huber e a borracha na Amazônia (1907-1914). Dissertação (Mestrado em História) - Universidade Federal do Pará. Belém, 2013.

COLETTA, Cristina Della (dir.). Turin 1911: The World's Fair in Italy. University of Virginia, 2009. Disponível em: http://www.italyworldsfairs. org/mainpage.html; Acesso em: 08 abr. 2015.

COLETTA, Cristina Della. World's fairs, Italian style: the great exhibitions in Turin and their narratives, 1860-1915. Toronto: University of Toronto Press, 2006.

CUNHA, Osvaldo Rodrigues da. Jacques Huber (1867-1914). Boletim do Museu Paraense Emílio Goeldi. Ciências Humanas, vol. 4, n. 3, p.489-502, 2009.

ERISH, Andrew A. Col. William N. Selig, the Man Who Invented Hollywood. Austin: University of Texas Press, 2012.

FISCHER, Diane P. Paris 1900: the 'American School' at the Universal Exposition. New Jersey: Rutgers University Press, 1999.

FISS, Karen. Grand Illusion: The Third Reich, the Paris Exposition, and the Cultural Seduction of France. Chicago: University of Chicago Press, 2010. FRAIHA NETO, Habib. Oswaldo Cruz e a febre amarela no Pará. Ananindeua: Editora IEC, 2012.

GEPPERT, Alexander Christian Tillmann; COFFEY, Jean; LAU, Tammy. International Exhibitions, Expositions Universelles and World's Fairs, 1851-2005: a bibliography. Freie Universität Berlin/California State University, 2006. Disponível em: http://www.csufresno.edu/library/ subjectresources/specialcollections/worldfairs/ExpoBibliography3ed. pdf; Acesso em: 08 abr. 2015.

GURSEL, Bahar. Two cities, two fairgrounds: Chicago's 1893 World's Columbian Exposition and Turin's 1911 International Exposition. In: CAROSSO, Andrea (ed.). Urban cultures of/in the United States: comparative perspectives. Bern: Peter Lang, 2010. p.63-86.

HARVEY, Penelope. Hybrids of Modernity: Anthropology, the Nation State and the Universal Exhibition. Oxford: Routledge, 1996.

LEVRA, Umberto; ROCCIA, Rosanna (eds.). Le esposizioni torinesi 1805-1911. Specchio del progresso e macchina del consenso. Turim: Archivio Storico della Città di Torino, 2003. 
LOUREIRO, Antonio José Souto. A grande crise. Manaus: Valer, 2008.

MASSARI, Stefania. Il fatale Millenovecentoundici. Le esposizioni di Roma, Torino, Firenze. Roma: Palombi \& Partner, 2012.

MORETTIN, Eduardo Victorio. As exposições universais e o cinema: história e cultura. Revista Brasileira de História, vol. 31, p.231-249, 2011 a. MORETTIN, Eduardo Victorio. Cinema e Estado no Brasil: a Exposição Internacional do Centenário da Independência em 1922 e 1923. Novos Estudos CEBRAP, n. 89, p.137-148, 2011 b.

MORETTIN, Eduardo Victorio. Um apóstolo do modernismo na Exposição Internacional do Centenário: Armando Pamplona e a Independência Film. Significação - Revista de Cultura Audiovisual, vol. 39, p.75-92, 2012.

MORETTIN, Eduardo Victorio. Uma construção luminosa: o cinema e a Exposição Internacional de 1937. Estudos Históricos, vol. 26, p.213-238, 2013. MORIONDO, Carlo. Torino 1911: La favolosa esposizione. Turim: Daniela Piazza, 1981.

MOURÃO, Leila. Memória da Indústria Paraense. Belém: Federação das Indústrias do Estado do Pará, 1989.

PALOMBI, Domenico. Rome 1911. L'Exposition archéologique du cinquantenaire de l'Unité italienne. Anabases - Traditions et Réceptions de l'Antiquité, vol. 9, p.71-99, 2009.

PEER, Shanny. France on Display: Peasants, Provincials, and Folklore in the 1937 Paris World's Fair. Albany: State University of New York Press, 1998. PICONE PETRUSA, Mariantonietta; PESSOLANO, Maria Raffaella; BIANCO, Assunta. Le grandi esposizioni in Italia, 1861-1911: la competizione culturale con l'Europa e la ricerca dello stile nazionale. Nápoles: Liguori, 1988.

RANGEL, Marcio Ferreira. Costa Lima e a campanha de combate à febre amarela no Rio de Janeiro e no Pará, Brasil. Revista Pan-Amazônica de Saúde, vol. 1, n. 1, p.19-26, 2010.

REZENDE, Livia Lazzaro. The raw and the manufactured: Brazilian modernity and national identity as projected in international exhibitions (1862-1922). Tese (Doutorado em Design) - Royal College of Art. London, 2010. 
RUEDIN, Pascal. Beaux-arts et représentation nationale: la participation des artistes suisses aux Expositions Universelles de Paris (1855-1900). Bern: Peter Lang, 2010.

RYDELL, Robert W.; FINDLING, John E.; PELLE, Kimberly D. Fair America. World's fairs in the United States. Washington: Smithsonian Institution, 2000.

SANCHEZ ARTEAGA, Juanma; NINO EL-HANI, Charbel. Physical anthropology and the description of the 'savage' in the Brazilian Anthropological Exhibition of 1882. História, Ciências, Saúde - Manguinhos, vol. 17, n. 2, p.399-414, 2010.

SANJAD, Nelson. Jacques Huber e a botânica amazônica: notas preliminares para uma biografia intelectual. In: JARDIM, Mario et al. (orgs.). Livro de Resumos. 54 Congresso Nacional de Botânica, Belém, SBB/ MPEG/Embrapa, jul. 2003. p.13-18.

SANTOS, Paulo Coelho Mesquita. O Brasil nas Exposições Universais (1862 a 1911): mineração, negócios e publicações. Dissertação (Mestrado em Ensino e História das Ciências da Terra) - Universidade Estadual de Campinas. Campinas, 2009.

SANTOS, Paulo Coelho Mesquita; COSTA, Adilson Rodrigues da. A Escola de Minas de Ouro Preto, a "Sociedade de Geographia Economica de Minas Geraes” e as Exposições Universais do final do século XIX e início do século XX. REM, vol. 58, n. 3, p.279-285, 2005.

SANTOS, Paulo Coelho Mesquita; COSTA, Adilson Rodrigues da. A Escola de Minas de Ouro Preto e as Exposições Universais. In: LEMOS, Paulo (org.). A História da Escola de Minas. Ouro Preto: Livraria e Editora Graphar, 2012. p.149-153.

SANTOS, Paulo Coelho Mesquita; COSTA, Adilson Rodrigues da. A Escola de Minas de Ouro Preto e as "Seções de Geologia" do Brasil nas Exposições Universais. REM, vol. 59, n. 3, p.347-353, 2006.

SANTOS, Roberto. História Econômica da Amazônia (1800-1920). São Paulo: T. A. Queiroz Editor, 1980.

SÃO PAULO, Pinacoteca do Estado de São Paulo. Turim 1911: vestígios de uma exposição universal. Pesquisa e curadoria de Ruth Sprung Tarasantchi. São Paulo: Pinacoteca do Estado de São Paulo, 2014. 
SCHUSTER, Sven. História, nação e raça no contexto da Exposição do Centenário em 1922. História, Ciências, Saúde - Manguinhos, vol. 21, n. 1, p.121-134, 2014.

STORM, Eric. The culture of Regionalism: Art, Architecture and International Exhibitions in France, Germany and Spain, 1890-1939. Manchester: Manchester University Press, 2010.

TENORIO-TRILLO, Mauricio. Mexico at the World's Fairs: crafting a modern nation. Berkeley: University of California Press, 1996.

TENORIO-TRILLO, Mauricio. Um Cuauhtémoc carioca: comemorando o Centenário da Independência do Brasil e a raça cósmica. Estudos Históricos, vol. 7, n. 14, p.123-148, 1994. 